\title{
Composition of the human foetus
}

\author{
By SHARAD V. APTE AND LEELA IYENGAR \\ National Institute of Nutrition, Indian Council of Medical Research, \\ famai-Osmania, Hyderabad-7 (A.P.), India
}

(Received I6 March 197I - Accepted 5 August I97I)

\begin{abstract}
I. The body composition was determined of forty-one foetuses of different gestational ages born to mothers belonging to a low socio-economic group of the population.

2. With increasing gestational age the water content fell from $88 \%$ at 28 weeks to $76 \%$ at term; the fat content increased from $2.1 \%$ to $\mathrm{II} \cdot 2 \%$ and the protein content increased from 6.9 to $9.3 \%$.

3. The changes in body composition were more closely related to body-weight than to gestational age.

4. The calcium, phosphorus and magnesium contents of the body per unit fat-free weight progressively increased with gestational age, and at term the values appeared to be considerably lower than those reported in the literature. The Ca: $\mathrm{P}$ ratio was constant at different bodyweights.

5. The body iron content per unit of fat-free weight increased marginally with increasing gestational age. This value was almost $30 \%$ lower than the values reported from elsewhere.

6. It is suggested that chemical composition and nutrient stores of the developing foetus can be considerably influenced by the state of maternal nutrition.
\end{abstract}

Satisfactory growth and development of the foetus may be expected to depend to a great extent on the diet and nutritional status of the mother. The chemical composition of the human foetus at different stages of gestation will provide base-line information not only on the chemistry of growth and development but also on the effects of maternal malnutrition on the body composition of the growing foetus.

While there is a good deal of information about the anthropometric measurements of the human foetus at varying gestational periods, information on the body composition at different stages of intra-uterine growth is limited. It is perhaps surprising that reported information on such a vital aspect of chemical development in utero is restricted to about only 120 foetuses; of these, about fifty were analysed around $\mathrm{AD}$ I900. Since information regarding the source of this material was not clearly indicated, Kelly, Sloan, Hoffman \& Saunders (r95r), in their review, have questioned the validity of these findings. More recent results are available for about seventy foetuses, which have been analysed for various body constituents (Givens \& Macy, r933; Iob \& Swanson, I934; Widdowson \& Dickerson, I964). Information on the total body iron content of twenty-five foetuses has been reported by Widdowson \& Dickerson (I964).

All these reports are from Europe and America and it may be presumed that the foetuses were born to well-nourished mothers. There are virtually no values for the body composition of foetuses born to mothers of the low socio-economic group whose dietary intake during pregnancy is far from satisfactory and among whom signs of malnutrition are frequently observed. The results of an investigation in which the body 
composition and mineral stores were determined in forty-one human foetuses of such malnourished mothers are presented here.

\section{MATERIALS AND METHODS}

Twenty-three immature foetuses of varying gestational ages and eighteen full-term infants born to mothers attending the Niloufer Hospital, Hyderabad, were obtained. The mothers belonged to the poor groups of the population, the family income generally being less than Rs. 150 per month. These women were similar to those studied earlier by Venkatachalam (1962), who had reported that they were undernourished, having a mean body-weight of about $42 \mathrm{~kg}$. They had clinical evidence of varying degrees of calorie and protein deficiency, vitamin B-complex deficiency and hypovitaminosis A. A mild to moderate anaemia was widely prevalent. The mean daily intakes of calories and protein were estimated to be $1400 \mathrm{kcal}$ and $40 \mathrm{~g}$ respectively. The intake of other nutrients was found to be grossly inadequate. Most of the women had not received any antenatal care. The gestational age was arrived at from information about the last menstrual period and may therefore be considered as approximate, the variation, however, being not greater than $\pm 7 \mathrm{~d}$. Body-weights of the infant have therefore been used as a reference standard for expressing body composition.

Twenty-nine foetuses were stillborn and twelve were born alive but expired within $24 \mathrm{~h}$. In sixteen the cause of stillbirth was either prepartum haemorrhage, eclampsia or compound presentation; in the other thirteen no cause could be detected.

\section{Preparation and analytical methods}

All the foetuses were preserved at $4^{\circ}$ before autopsy, which was usually performed within $6-8 \mathrm{~h}$ of death. They were dissected to small pieces in an aluminium tray to prevent loss of blood. The liver was removed, washed and analysed separately (Iyengar \& Apte, 1972). The dissected foetuses were dried in a hot-air oven at $90-100^{\circ}$ for I $5^{-20}$ d. The whole dried foetus was powdered in small quantities at a time in a glass mortar and pestle. All the powdered lots were thoroughly mixed and stored dry at room temperature. Duplicate samples of $5^{-10} \mathrm{~g}$ of the whole carcass powder were initially used for determination of fat. Samples of fat-free powder were used for determination of nitrogen, calcium, phosphorus, magnesium and iron.

Fat was determined by ether extraction in Soxhlet's apparatus for $16 \mathrm{~h} . \mathrm{N}$ was determined by the micro-Kjeldhal method with aeration into boric acid and tritation (Oser, 1965). $\mathrm{N}$ conversion into protein was calculated by the factor 6.25 . Ca was measured by the method of Clark \& Collip (1925), P by the method described by the Association of Official Agricultural Chemists (1960), Mg by the method of Orange $\&$ Rhein (I95I) and Fe by a thiocyanate method (Wong, I928). 
RESULTS

The results are presented in Tables $\mathrm{I}-3$ and are compared with those reported by Widdowson (1968) in Table 4.

\section{Water, protein and fat}

Foetal body-weight, fat and protein concentration increased, and water concentration decreased with increasing time of gestation. The concentrations of water, fat and protein $(Y)$ in the developing foetus were significantly correlated with body-weight $(x)$, the regression equations being

$$
\begin{gathered}
\text { Water: } Y=9 \mathrm{r} \cdot 92-0.0059 x \quad(r=-0.8581)^{* * *} ; \\
\text { Fat: } Y=0.0049 x-2.25 \quad\left(r=+0.333^{*}\right)^{*} \\
\text { Protein: } Y=7.33+0.00078 x \quad\left(r=+0.333^{8}\right) . * \\
* P<0.05 ; * * * \quad P<0.001 .
\end{gathered}
$$

There was a progressive fall in the concentration of water with increasing bodyweight. The water content ( $\mathrm{g} / 100 \mathrm{~g}$ wet weight) of the smallest foetus, weighing $0.23 \mathrm{~kg}$, was about $93 \%$, whereas that of the foetus weighing $3.3 \mathrm{~kg}$ was about $72 \%$. Body water expressed as a percentage of lean body mass fell from $91 \%$ to about $84 \%$ when the weight was about $3.3 \mathrm{~kg}$. Fat constituted $0.3 \mathrm{~g} / \mathrm{I} 00 \mathrm{~g}$ body-weight at $0.23 \mathrm{~kg}$ and $16 \mathrm{~g} / \mathrm{I} 00 \mathrm{~g}$ at $3.3 \mathrm{~kg}$ body-weight. The protein concentration increased from a mean of $6.9 \mathrm{~g} / \mathrm{roO} \mathrm{g}$ at gestational age below 28 weeks to $9.3 \mathrm{~g} / \mathrm{l} 00 \mathrm{~g}$ at term. There appeared to be no significant difference in this respect between foetuses of different body-weights at term. Similarly, the percentage of fat increased progressively from some $2 \cdot 1 \mathrm{~g} / \mathrm{1} 00 \mathrm{~g}$ below 28 weeks to $5.6 \mathrm{~g} / \mathrm{IO0} \mathrm{g}$ at term in foetuses whose bodyweights were below $2 \cdot 25 \mathrm{~kg}$ and to $\mathrm{II} \cdot 2 \mathrm{~g} / \mathrm{roO} \mathrm{g}$ in foetuses whose body-weights were above $2 \cdot 25 \mathrm{~kg}$.

$$
\mathrm{Ca}, \mathrm{P} \text { and } \mathrm{Mg}
$$

A steady increase in the absolute amounts of $\mathrm{Ca}, \mathrm{P}$ and $\mathrm{Mg}$ was observed with increasing body-weight, the total amounts at $3.3 \mathrm{~kg}$ body-weight being fourteen and fifteen times that of the foetus weighing $0.34 \mathrm{~kg}$ (Table 3). On a fat-free basis the percentage also increased, the concentration of $\mathrm{Ca}$ at term being little less than twice, and that of $\mathrm{P}$ being about $\mathrm{I} \cdot 7$ times, that found in a foetus weighing $0.34 \mathrm{~kg}$. The $\mathrm{Mg}$ concentration steadily increased up to a body-weight of $\mathrm{r} \cdot 70 \mathrm{~kg}$ and thereafter remained stationary. The $\mathrm{Ca}: \mathrm{P}$ ratio remained relatively constant within a range of $I \cdot 6-2 \cdot I$ at different body-weights.

$$
F e
$$

The total amount of Fe in the foetuses at different body-weights is shown in Fig. $\mathrm{I}$. The increase in the absolute amount of Fe showed a linear relation with body-weight. The concentration of Fe per Ioo g fat-free body-weight, however, increased only slightly, from $5.3 \mathrm{mg}$ at $0.23 \mathrm{~kg}$ body-weight to $6.4 \mathrm{mg}$ at $3.3 \mathrm{~kg}$. There were wide variations among the values at any one body-weight. 
Table I. Body composition of the human foetus

\begin{tabular}{|c|c|c|c|c|c|c|c|c|c|}
\hline $\begin{array}{c}\text { Age } \\
\text { (weeks) }\end{array}$ & $\begin{array}{c}\text { Body- } \\
\text { wt } \\
(\mathrm{g})\end{array}$ & $\begin{array}{c}\text { Water } \\
(\%)\end{array}$ & $\begin{array}{r}\text { Fat } \\
(\%)\end{array}$ & $\begin{array}{c}\text { Pro- } \\
\text { tein } \\
(\%)\end{array}$ & $\begin{array}{l}\text { Ash } \\
(\%)\end{array}$ & $\begin{array}{c}\mathrm{Ca} \\
(\%)\end{array}$ & $\begin{array}{c}\mathrm{P} \\
(\%)\end{array}$ & $\begin{array}{c}\mathrm{Mg} \\
(\mathrm{mg} / \mathrm{r} 00 \mathrm{~g})\end{array}$ & $\begin{array}{c}\mathrm{Fe} \\
(\mathrm{mg} / \mathrm{I} \circ \mathrm{g})\end{array}$ \\
\hline 20 & 230 & $93 \cdot 2$ & 0.3 & 4.0 & $I \cdot I 5$ & 0.322 & 0.241 & I $2 \cdot 0$ & 4.5 \\
\hline 24 & $45^{\circ}$ & $88 \cdot 2$ & $I \cdot I$ & $8 \cdot 3$ & I.95 & 0.557 & 0.294 & 19.2 & 5.9 \\
\hline 24 & 790 & $89^{\circ}$ & $\mathrm{I} \cdot 5$ & $6 \cdot 7$ & $I \cdot 96$ & 0.704 & 0.340 & $17^{\circ} \mathrm{O}$ & 5.1 \\
\hline 26 & 655 & $90 \cdot 6$ & $x \cdot 5$ & $6 \cdot 4$ & $I \cdot 45$ & 0.502 & 0.269 & 14.3 & $3 \cdot 6$ \\
\hline 26 & 570 & 83.9 & $2 \cdot 0$ & $9^{2} 2$ & $2 \cdot 53$ & 0.834 & 0.514 & $27 \cdot 3$ & $5^{\circ} 0$ \\
\hline 26 & 810 & 90.8 & 0.7 & $7 \cdot 0$ & $I-40$ & 0.387 & $0.27 \mathrm{I}$ & $17 \cdot 1$ & $4 \cdot I$ \\
\hline 26 & 1035 & 87.0 & $1 \cdot 4$ & $7 \cdot 9$ & 2.19 & 0.686 & 0.355 & $22 \cdot 3$ & $4 \cdot 3$ \\
\hline 26 & 1320 & $8 \mathrm{I} \cdot 8$ & $8 \cdot I$ & $6 \cdot I$ & $2 \cdot 24$ & 0.613 & 0.325 & $I 7 \cdot 2$ & $5 \cdot 2$ \\
\hline 28 & 1030 & $82 \cdot 5$ & $2 \cdot 0$ & $11 \cdot 7$ & 2.73 & 0.700 & 0.575 & 23.5 & $5 \cdot 8$ \\
\hline 28 & 1100 & 80.5 & $5^{\circ} 0$ & I I 99 & $2 \cdot 53$ & 0.392 & 0.337 & 20.0 & $6 \cdot 9$ \\
\hline 29 & 1210 & 89.7 & $2 \cdot 3$ & $5 \cdot 9$ & I' 45 & 0.429 & 0.241 & I $3 \cdot 3$ & $3 \cdot 8$ \\
\hline 29 & I 560 & $85 \cdot 1$ & $3 \cdot 4$ & $7 \cdot 7$ & $2 \cdot 32$ & 0.835 & $0.42,4$ & I 3.6 & 42 \\
\hline 30 & I 420 & 89.0 & $I \cdot 4$ & $7 \cdot 9$ & $2 \cdot 42$ & 0.720 & 0.457 & $19 \cdot 6$ & $5 \cdot 6$ \\
\hline 30 & 1425 & $8 I \cdot I$ & $4 \cdot 3$ & $9 \cdot 7$ & $2 \cdot 72$ & 0.924 & 0.529 & $20 \cdot 6$ & 5.8 \\
\hline 32 & 925 & $89 \cdot 2$ & $1 \cdot 6$ & $5^{\circ} 9$ & 2. I9 & $0.3 \circ 3$ & 0.418 & I $7 \cdot 5$ & 42 \\
\hline 32 & I 100 & $84 \cdot 8$ & $3 \cdot 6$ & $7 \cdot 4$ & $2 \cdot 23$ & 0.688 & 0.358 & II 8 & $6 \cdot 9$ \\
\hline 32 & I I 50 & $82 \cdot 6$ & $2 \cdot 7$ & 10.3 & $3 \cdot 19$ & $I \cdot I 5 I$ & 0.637 & $23 \cdot I$ & $7 \cdot 2$ \\
\hline 32 & 1340 & 83.9 & $5 \cdot 5$ & $7 \cdot I$ & $2 \cdot 18$ & 0.769 & 0.413 & I 2.4 & 54 \\
\hline 35 & 1055 & 87.0 & $2 \cdot 6$ & $7 \cdot 4$ & $1 \cdot 74$ & 0.623 & 0.276 & I 6.9 & $5^{2}$ \\
\hline 35 & 1840 & $8 I \cdot 9$ & $5 \cdot 7$ & 8.8 & $2 \cdot 55$ & 0.389 & 0.222 & $21 \cdot 1$ & $4^{\cdot} \cdot 1$ \\
\hline 36 & $129^{\circ}$ & $83^{\circ} 0$ & $4 \cdot 4$ & IO'I & 240 & 0.898 & 0.417 & $2 I \cdot 6$ & $5^{-9}$ \\
\hline 36 & I 520 & $84 \cdot I$ & $4 \cdot 2$ & 9.0 & $\mathrm{x} \cdot 89$ & 0.757 & 0.364 & 19.4 & $6+1$ \\
\hline 36 & I 570 & $8 \pi \cdot 0$ & $5^{\circ} 9$ & $7 \cdot 8$ & $2 \cdot 19$ & 0.849 & 0.395 & $24 \cdot I$ & 57 \\
\hline 37 & I 800 & $83 \cdot 3$ & $4 \cdot 4$ & $9 \cdot 3$ & 2.54 & 0.928 & 0.504 & 24.7 & 6.1 \\
\hline 38 & 2230 & $78 \cdot 3$ & $8 \cdot I$ & 8.6 & $2 \cdot 0.5$ & 0.656 & 0.512 & $21 \cdot 7$ & 4.5 \\
\hline 38 & 2495 & $74 \cdot 7$ & 13.0 & $7 \cdot 3$ & 173 & $0.78 \mathrm{I}$ & 0.313 & 20.5 & $7 \cdot \mathbf{I}$ \\
\hline 38 & 2600 & $75 \cdot 2$ & 12.4 & $8 \cdot 9$ & $\mathrm{I} \cdot 95$ & 0.718 & 0.374 & 18.9 & $4^{\cdot} \mathrm{I}$ \\
\hline $3^{8}$ & 2645 & $78 \cdot 1$ & $8 \cdot 6$ & 100 & $2 \cdot 09$ & 0.727 & 0.374 & $2 x \cdot 9$ & $5 \cdot 8$ \\
\hline 40 & rogo & $83 \cdot 8$ & $2 \cdot 8$ & 10.7 & 2.49 & 0.762 & 0.456 & $22 \cdot 4$ & $5 \cdot 5$ \\
\hline 40 & I 975 & $82 \cdot 0$ & 5.5 & $8 \cdot 5$ & $I .45$ & 0.527 & 0.297 & $18 \cdot 6$ & $6 \cdot 1$ \\
\hline 40 & 2000 & $79 \cdot 3$ & 74 & $\mathbf{I} \mathbf{I} \cdot \mathbf{I}$ & $2 \cdot 01$ & 0.625 & 0.354 & $I 6 \cdot x$ & $4 \cdot 3$ \\
\hline 40 & 2010 & $78 \cdot 3$ & $5 \cdot 6$ & II 2 & $2 \cdot 41$ & 0.879 & 0.604 & $28 \cdot 3$ & $5 \cdot 3$ \\
\hline 40 & 2270 & $76 \cdot 5$ & 93 & 10.0 & $2 \cdot 54$ & 0.849 & 0.471 & 18.6 & $6 \cdot 2$ \\
\hline 40 & 2280 & 747 & $x \times \cdot 7$ & 10.9 & $I \cdot 64$ & 0.391 & 0.247 & 16.9 & $6 \cdot 4$ \\
\hline 40 & 2400 & 80.6 & 90 & $6 \cdot 3$ & $2 \cdot 33$ & 0.844 & 0.432 & 19.5 & 5.4 \\
\hline 40 & $25 \circ 5$ & $73 \cdot 2$ & $12 \cdot 6$ & 10.4 & $3 \cdot 17$ & $1 \cdot 050$ & 0.522 & $21 \cdot 7$ & $6 \cdot 4$ \\
\hline 40 & 2535 & $74^{\circ} \circ$ & $12 \cdot 4$ & $9 \cdot 3$ & $2 \cdot 37$ & 0.879 & 0.352 & $21 \cdot 5$ & $4 \cdot 3$ \\
\hline 40 & 2600 & $78 \cdot 7$ & 6.7 & 10.5 & $3 \cdot 4 \mathrm{r}$ & $\mathrm{I} \cdot 06_{4}$ & 0.526 & 29.8 & $7 \cdot 1$ \\
\hline 40 & 2680 & $78 \cdot 5$ & $I \times \cdot 6$ & $9 \cdot 3$ & I' I I & 0.304 & 0.179 & $15 \cdot 1$ & $3 \cdot 3$ \\
\hline 40 & $327^{\circ}$ & $78 \cdot 3$ & I I ' 3 & $7 \cdot 8$ & $x \cdot 65$ & $0.55^{8}$ & 0.312 & $16 \cdot I$ & $5 \cdot 5$ \\
\hline 40 & 3340 & $71 \cdot 5$ & 15.8 & $9 \cdot 2$ & $2 \cdot 61$ & 0.934 & $0 \cdot 469$ & $27 \cdot 8$ & $5^{6} 6$ \\
\hline
\end{tabular}

\section{Table 2. Body composition of the human foetus}

(Mean values with their standard errors; figures in parentheses are the numbers of foetuses studied)

\begin{tabular}{|c|c|c|c|c|c|}
\hline Age (weeks) & $\begin{array}{c}\text { Body-weight } \\
\text { (g) }\end{array}$ & $\begin{array}{c}\text { Water } \\
\text { (g/100 g) }\end{array}$ & $\begin{array}{c}\text { Fat } \\
(\mathrm{g} / \mathrm{I} 00 \mathrm{~g})\end{array}$ & $\begin{array}{l}\text { Protein } \\
(\mathrm{g} / \mathrm{I} 00 \mathrm{~g})\end{array}$ & $\begin{array}{c}\text { Ash } \\
(\mathrm{g} / \mathrm{I} / 00 \mathrm{~g})\end{array}$ \\
\hline$<28(8)$ & $733.4 \pm I 20.04$ & $88 \cdot \mathbf{1}=$ & $2.1 \pm 0.88$ & $6 \cdot 9 \pm 0 \cdot 5^{6}$ & $I \cdot 9 \pm 0 \cdot 17$ \\
\hline $28-32$ (10) & $1225^{\circ} 7 \pm 64.07$ & $84 \cdot 8 \pm 1 \cdot 08$ & $3.2 \pm 0.45$ & $8.6 \pm 0.70$ & $2 \cdot 4 \pm 0.15$ \\
\hline $\begin{array}{l}33-36(5) \\
37-40:\end{array}$ & $1454: 4 \pm 132 \cdot 55$ & $83 \cdot 8 \pm \mathrm{r} \cdot 05$ & $4 \cdot 6 \pm 0.59$ & $8 \cdot 6 \pm 0.48$ & $2 \cdot 2 \pm 0 \cdot 15$ \\
\hline $\begin{array}{l}\text { Body-wt } \\
<225 \circ \text { g (6) }\end{array}$ & $1850.0 \pm 162 \cdot 02$ & $80 \cdot 8 \pm 1 \cdot 03$ & $5.6 \pm 0.79$ & $9.9 \pm 0.5 x$ & $2 \cdot 2 \pm 0 \cdot 17$ \\
\hline $\begin{array}{l}\text { Body-wt } \\
>225^{\circ} \mathrm{g} \text { (I2) }\end{array}$ & $2635 \cdot 3 \pm 97 \cdot 90$ & $76 \cdot 2 \pm 0 \cdot 78$ & II. $2 \pm 0.70$ & $9.3 \pm 0.36$ & $2 \cdot 2 \pm 0 \cdot 19$ \\
\hline
\end{tabular}



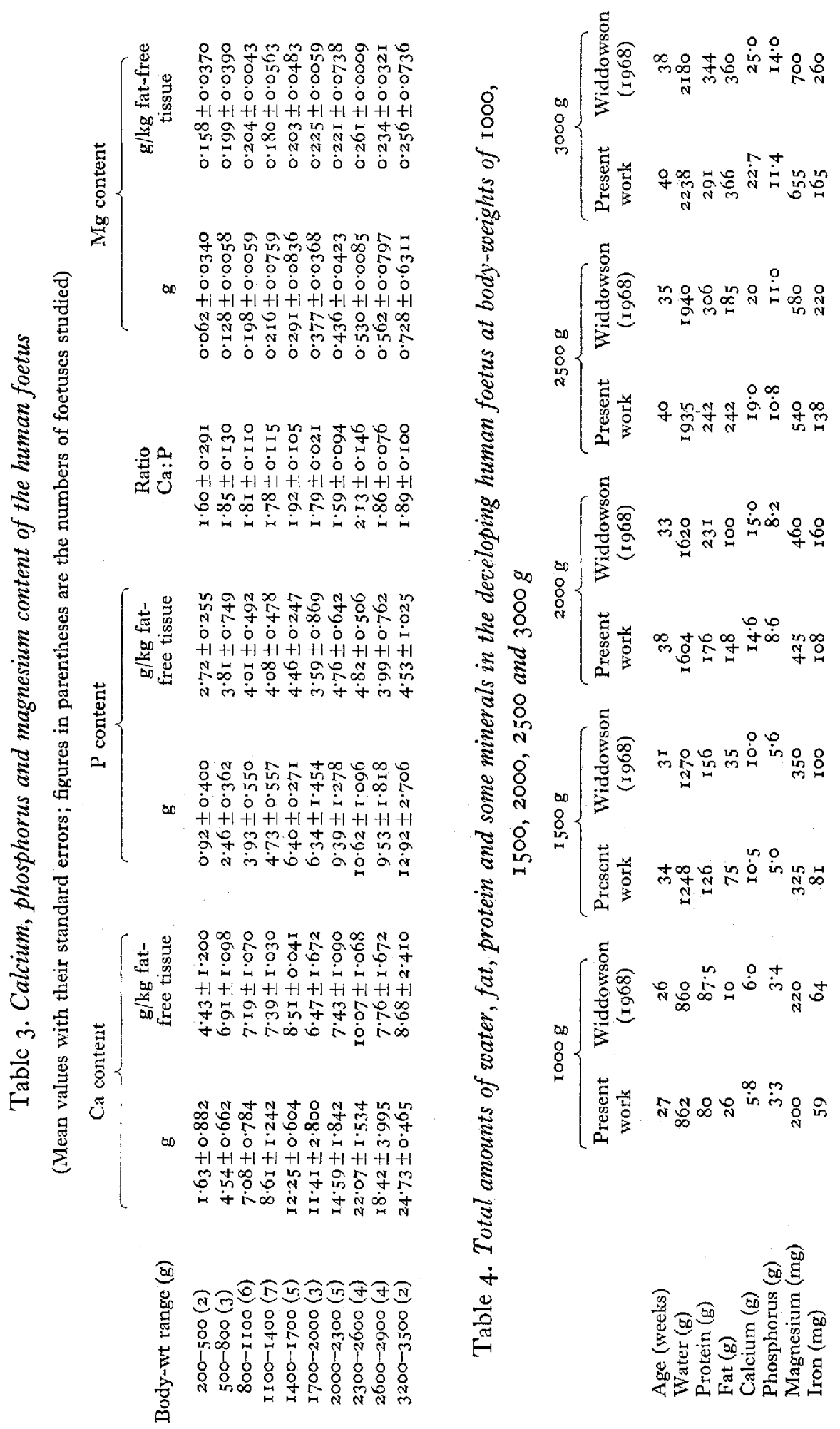

in \{

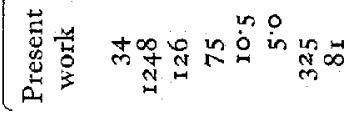

5

ड़े

b

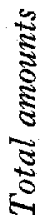

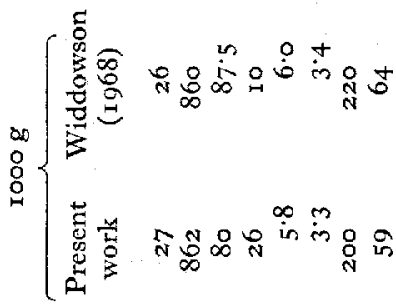




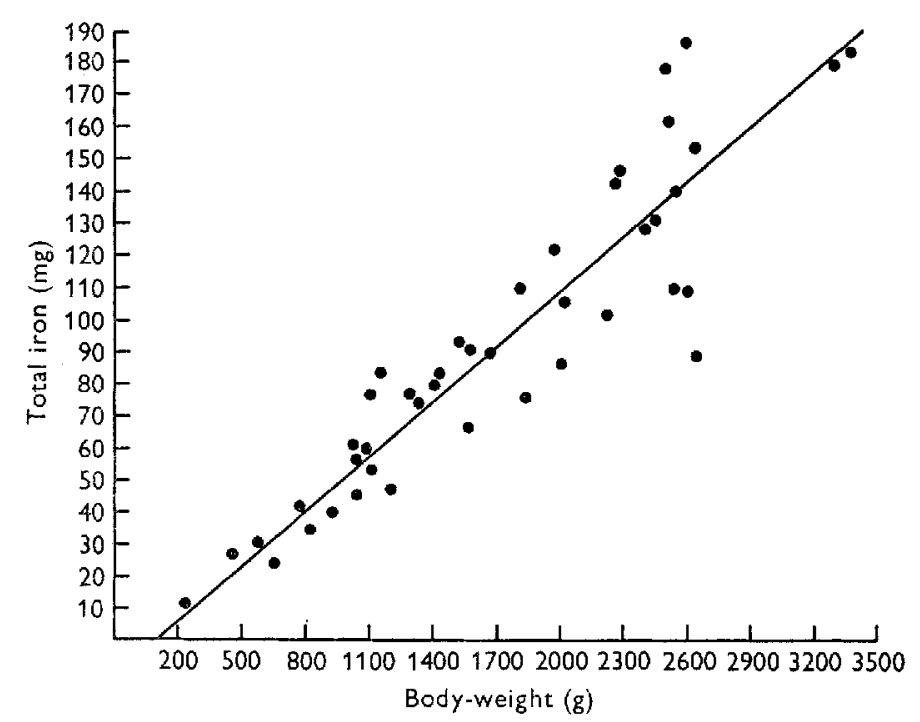

Fig. I. Total iron in the human foetus. Regression equation relating total iron $(Y)$ to bodyweight $(x): Y=0.0560 x-3.70(r=+0.9145)^{* * *}$.

*** $P<0.001$.

\section{DISCUSSION}

With increasing body-weight one of the striking changes in the body composition was the decrease in water content, both in relation to total body-weight and in relation to fat-free body-weight. A similar but more marked decrease in water content has been reported by Widdowson \& Spray (195I) in foetuses in the United Kingdom. The fat content of foetuses studied here was similar to that of those studied by Widdowson \& Spray (195I) at all weights. In fact, in foetuses of 40 weeks gestation weighing $2.50 \mathrm{~kg}$, the fat content was slightly higher than that reported by Widdowson 8 Spray (195I) for foetuses of similar weight, but of only 35 weeks gestation. It is possible that this difference is an expression of foetal maturity. The results of the present investigation indicate that the amount of fat deposited in the developing foetus is more closely related to body-weight than to period of gestation. The low fat content of foetuses studied here may be a reflection of the low body-weight. The percentage of fat in foetuses at term studied here is similar to that reported by Shohl (r939).

The $\mathrm{N}$ content of foetuses at all body-weights was distinctly lower than that observed by Widdowson \& Spray (195I). At about 20 weeks of gestational age, foetuses analysed here contained $0.7 \mathrm{~g} / \mathrm{I} 00 \mathrm{~g}$ as compared with $\mathrm{r} \cdot 3 \mathrm{~g} / \mathrm{I} 00 \mathrm{~g}$ reported by Widdowson \& Spray (195 I). However, during the last 20 weeks of development an increment of $\mathrm{I} g / \mathrm{IOO} \mathrm{g}$ in $\mathrm{N}$ content was observed in both studies. The results could be interpreted as indicating that, in the initial phases of development, foetuses in the present study had more water and less protein, but similar amounts of fat compared with those studied by Widdowson \& Spray (195r). Examination of our results and those of Widdowson \& Spray (I95I) indicates that, in both series, with the development of 
the foetus the protein and fat content increased almost similarly. However, it would appear that the water content decreased at different rates in the two series.

Total $\mathrm{Ca}$ and $\mathrm{P}$ contents of the foetuses were similar to reported values up to a body-weight of $2 \mathrm{~kg}$. However, foetuses of body-weight greater than $2 \mathrm{~kg}$ tended to have slightly smaller amounts of $\mathrm{Ca}$ and $\mathrm{P}$ than those of Widdowson (rg68). The total $\mathrm{Mg}$ content of Indian foetuses was lower by 6-9\% than that of Western foetuses at each body-weight.

There were wide variations in the total Fe content of foetuses of the same weight, an observation similar to that reported in the literature (Widdowson \& Spray, 195I). The total Fe content of foetuses in the present study, however, was significantly lower than that of Western foetuses at all weights. This was also true of the concentration of $\mathrm{Fe} / \mathrm{I} 00 \mathrm{~g}$ fat-free weight.

On the basis of body-weight, at 26-28 weeks of gestational age the foetuses in this series were similar to those from the West, but beyond this period there appeared to be a definite lag in body-weight of roughly $3-5$ weeks. It may, however, be considered significant that, even when the body-weights were similar, their composition was slightly different, there being a marked deficit in the protein and $\mathrm{Fe}$ contents. The total protein content was lower by $8 \%$ in the earlier stages and by as much as $23 \%$ in the later stages of development. Similarly the $\mathrm{Fe}$ content was lower by $20 \%$ at all stages. In our series the fat contents of foetuscs weighing I and $\mathrm{r}_{5} 5 \mathrm{~kg}$ were $26 \mathrm{~g}$ and $75 \mathrm{~g}$ respectively. The lower fat content ( $\mathrm{rog}$ and $35 \mathrm{~g}$ ) of British foetuses of similar body-weight (Table 4) is intriguing, since Widdowson (1968) in the same paper had observed that the percentage of fat at a body-weight of $\mathrm{I} \cdot 2 \mathrm{~kg}$ and foetal age of 28 weeks was about $3.5 \%$.

It is difficult to explain the low amounts of protein in the foetuses of the present study. It may be a reflection of the poor nutritional status of the mother. The low Ca and $\mathrm{Fe}$ contents may again perhaps be due to inadequate intake of these nutrients by the pregnant mothers.

The authors thank Dr C. Gopalan and Dr S. G. Srikantia for their advice and for reviewing the manuscript. They also thank Dr I. S. Shanolikar for his help and Mr K. Visweswara Rao for the statistical analysis. Mr D. Laxminarayana rendered technical assistance.

\section{REFEREN CES}

Association of Official Agricultural Chemists (I960). Official Methods of Analysis 9th ed., p. 84. Washington, DC: Association of Official Agricultural Chemists.

Clark, E. P. \& Collip, J. B. (1925). F. biol. Chem. 63, 46r.

Givens, M. H. \& Macy, I. G. (1933). F. biol. Chem. 102, 7 .

Iob, V. \& Swanson, W. W. (1934). Am. 7. Dis. Child. 47, 302.

Iyengar, J. \& Apte, S. V. (1972). Br. F. Nutr. 27, 313.

Kelly, H. J., Sloan, R. E., Hoffman, W. \& Saunders, C. (195r). Hum. Biol. 23, 6r.

Orange, M. \& Rhein, H. C. (195 I). F. biol. Chem. 189, 379.

Oser, B. L. (1965). Hawk's Physiological Chemistry 14th ed., p. 1219. New York: McGraw-Hill Book Company.

Shohl, A. T. (1939). Mineral Metabolism. American Chemical Society Monograph Series. New York: Reinhold Publishing Corporation. 
Venkatachalam, P. S. (1962). Bull. Wld Hlth Org. 26, 193.

Widdowson, E. M. (1968). In Biology of Gestation Vol. 2, p. 23 [N. S. Asali, editor]. New York: Academic Press.

Widdowson, E. M. \& Dickerson, J. W. T. (1964). In Mineral Metabolism Vol. 2, Part A The Elements, Processes and Systems p. 26 [C. L. Comer and F. Bronner, editors]. New York: Academic Press.

Widdowson, E. M. \& Spray, C. M. (I95I). Archs Dis. Childh. 26, 205.

Wong, S. Y. (1928). F. biol. Chem. 77, 409. 